\title{
crítica de exposición
}

\section{A veces, siempre: Robert Mapplethorpe. CAC Málaga, 11 de septiembre/ 15 de noviembre de 2009}

\author{
Miguel Ángel Fuentes Torres
}

Investigador vinculado a la UMA

\author{
“...lo que denominamos identi- \\ dad es un logro siempre precario \\ que es constantemente socava- \\ da por los deseos reprimidos \\ que constituyen el inconsciente". \\ José Miguel G. CoRtés
}

De dentro hacia fuera. Recordar la intimidad de la mirada. Atesorar la calidez de las horas arrebatadas al paso del tiempo mientras la curvatura del espectro anacrónico de los días que transcurren se divierte en su fortaleza de irrepetible belleza. Como imágenes que se instalan en la memoria intacta del espectador, la piel se va componiendo mediante la intangible presencia de las manos que ansían la levedad del tacto. Así, en la constancia del instante y en la inconsistencia de la verdad sumisa se va construyendo la historia de los cuerpos.

Casi en este extinto año que requiere de su temporalidad la seguridad de su finitud, el Centro de Arte Contemporáneo de Málaga, trae hasta el espectador la ubicación atemperada y precisa de una extensa colección de fotografías en las que su responsable, Robert Mapplerhorpe queda, a veces (siempre), representado de alguna forma. Esta circunstancia avala la importancia de la misma, asegurando, incluso, la indagación sobre diversos aspectos que, en su constante discurrir, construyen la muestra desde dentro hacia fuera. De hecho, en todo momento, la sensación de plenitud fotográfica se aprecia constatando la importante labor desarrollada, en su particular parcela de trabajo, por este autor. La imagen se convierte así en detalle que acumula detalles, presencia que enmarca experiencias y soporte que re-conduce la visión hacia otros lugares en los que también se reconoce como si de un simple juego de relaciones se tratara: exponer lo evidente para mostrar lo subyacente.

Mapplethorpe es por encima de todo fotógrafo, observador de su realidad y artífice de imágenes. Profundiza con elegancia y solvencia en los matices del soporte al tiempo que relativiza la fuerza de las expresiones, los gestos, las acciones y los momentos, derivando su preocupación hacia el clímax de lo acontecido. Sus inicios en el medio son reflejo de su propia trashumancia cotidiana, un deambular que le imprime una fuerte amplitud de perspectivas, todas ellas clarificadoras. Su interés por 


\section{crítica de exposición}

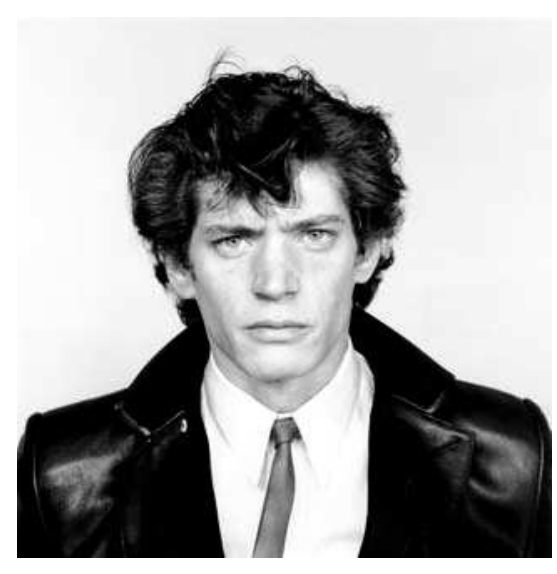

2. ROBERT MAPPLETHORPE Lydia Cheng, 1985 Gelatina de plata $41 \times 51 \mathrm{~cm}$ Lydia Cheng, 1985 ( ) Robert

Mapplethorpe Foundation. Reproducido con permiso
1. ROBERT MAPPLETHORPE Self Portrait, 1982 Gelatina de plata $41 \times 51 \mathrm{~cm}$ Self Portrait,1982 (C) Robert Mapplethorpe Foundation. Reproducido con permiso.

la fotografía participa también de una aproximación al sentido y significado del soporte como vehículo expresivo. No en vano, sus trabajos acaban incidiendo en la utilización de la Polaroid, mucho más cercana a esa inmediatez de la que hace gala en numerosas propuestas. Sin embargo, sus orígenes le llevan hasta el siglo XIX, teniendo en Nadar a uno de sus grandes pasiones para luego ir centrando su objetividad hacia las remiscencias pop y las aperturas del conceptualismo en el Nueva York de los setenta. Allí se convierte en testigo y participante de la escena underground, situando sus intenciones en el marco de la publicidad y recogiendo, de igual forma, todas las connotaciones de los círculos creativos del momento. Es desde aquí donde parte el recorrido de esta muestra que finaliza prácticamente con la muerte del artista en 1989, evidenciando la enorme capacidad de reducción del sentido de la acción a pequeñas instantáneas llenas de historias, repletas de un extraño artificio pero singulares en su pequeña parcela de reconocimiento. Su universo fotográfico se 


\section{crítica de exposición}
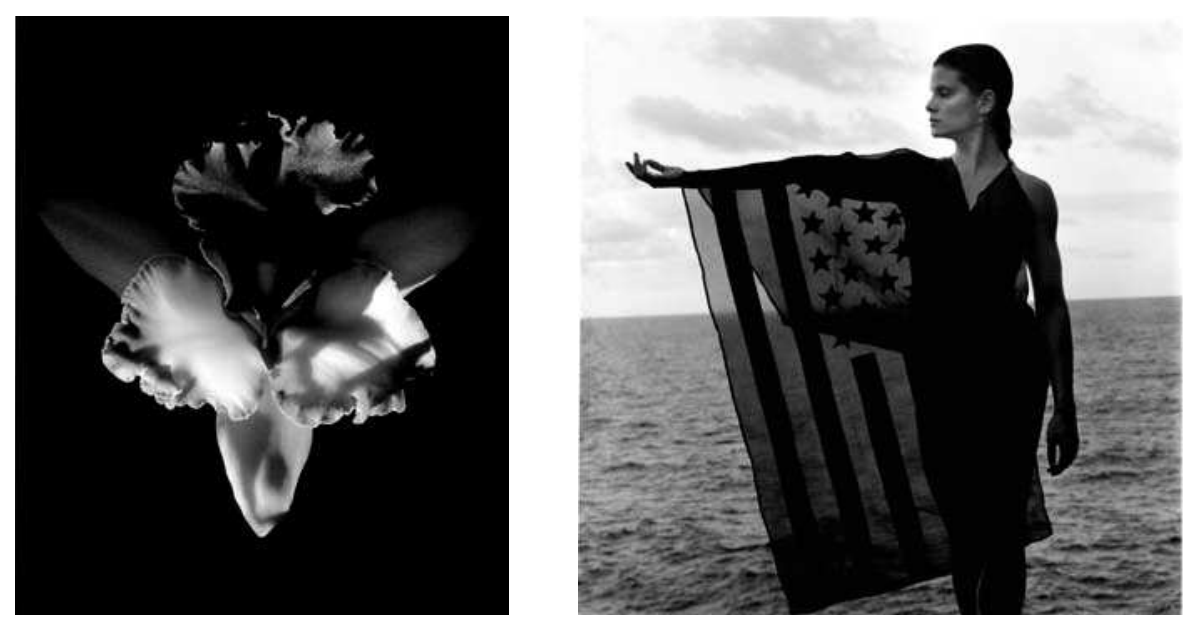

3. ROBERT MAPPLETHORPE Orchid, 1985 Gelatina de plata $41 \times 51 \mathrm{~cm}$ Orchid,1985 (C) Robert Mapplethorpe Foundation. Reproducido con permiso.

4. RoBert MAPPLETHORPE Lisa Lyon, 1982 Gelatina de plata 41 × $51 \mathrm{~cm}$ Lisa Lyon, 1982 (C) Robert Mapplethorpe Foundation. Reproducido con permiso.

eleva sobre un cúmulo de apreciaciones que circulan entorno al retrato, el bodegón o el estudio del cuerpo humano, a la postre, pistas que nos ilustran sobre su giro clasicista. Y en todo el proceso, el sexo como lugar hacia donde dirigir la atención del objetivo, proyectando aquí la impronta de un creador auspiciado por un interés perenne. Ante el objetivo de su cámara posan toda una extensa gama de personajes, artífices, realizadores, a veces reconocibles, a veces anónimos pero siempre hacedores de la realidad que de manera precisa se instala en sus ojos.

En esta ocasión son varias las series que se presentan bajo el halo de reminiscencia conmemorativa, de retrospectiva que acerca hasta el espectador una compleja, pero accesible, contemporaneidad de la fotografía. Al juego implacable de la Polaroid se une la elegancia del blanco y negro como marco de representación, atribuyendo a las composiciones un sentido de eternidad, de estar ahí desde siempre. Su incorformismo aparece siempre en su forma de afrontar las disposiciones que la vida le preparó no si cierta voracidad intimista. Al respecto, Peter Weirmair afirma que "las fotografías polaroid también se convirtieron en el reflejo de una personalidad aún bastante "activista", captada en instantes cándidos pero profundamente personales". Localizamos aquí esa pretensión de trascedener, de apremiar en la captación para deleitar con el instante la confrontación presente en la realidad que día a 


\section{crítica de exposición}

día marcaba su devenir como ser humano. Estamos, por tanto, ante una mirada ante la vida, ante una disposición que nacía del propio individuo y desembocaba en la misma sociedad. Así, cuando Blas Fernández Gallego se refiere a Mapplethorpe lo define como "una nueva versión del dandy rebelde, no revolucionario, aflorando a la sociedad puritana americana un enfrentamiento morboso, la utilización del hombre de color como objeto sexual deseable, eróticamente envidiable y que puede extenderse a los estratos sociales que desdeñaron a la par que "utilizaron" ese comportamiento".

Desde dentro hacia fuera, así parecen funcionar las imágenes que pueblan los muros blanco del espacio expositivo. Es aquí donde re-toman la sensación de aproximación al momento mediante la interpretación visual que resulta de su contemplación calmada, asumida desde la intimidad del espectador que también participa de la generalidad que supone su inmersión en la dimensión espectacular. Y por encima de todo el sujeto o el cuerpo, sus dimensiones y sus posibilidades arrebatadas al tiempo mientras se construye la escena para dejarse llevar después por la celeridad de la continuidad consumada. Intentar averiguar que nos dicen las miradas de quienes se acercan hasta el objetivo de Mapplethorpe es indagar no solamente en la constancia del individuo en su naturaleza (Cynthia Slater, 1980) sino también en el reflejo de sus ojos como lugar donde desemboca la vida (Deborah Harry, 1978).

Por otra parte y atendiendo al sentido interior, es decir, a la mirada interna que sirve de trampolín para la experiencia, resulta intrigante pensar en la intrahistoria de las imágenes, en esas conversaciones previas al disparo definitivo, al sentido de conclusión que destilan esas composiciones donde la marea primaria del ser humano se traviste bajo la "apariencia" de sexo programado (Marty and Veronica, 1982). Además, todo ocurre en un estudio, en una habitación, aislada, sumida en el deseo de apertura y reclamo que supone la persistencia de quien asevera con la cámara mientras construye pequeños trozos de contidianeidad. Su tiempo y su memoria son los pilares sobre los que también se levanta la maestría de quien, con pocos medios, es capaza de transmitir tanta humanidad: ahí reside igualmente la singularidad del medio fotográfico. incluso, cuando su interés se acerca hasta la naturaleza, ésta aparece individualizada y evocadora, haciendo que sus verdades lleguen hasta nosotros como pequeñas intimidades que nos hacen más humanos.

Toda la producción de Robert Mapplethorpe confluye en su idea de belleza, una belleza que circunda sus fotografías y es depositada en los ojos de quien es atrapado por su objetivo, en las líneas de los cuerpos que juegan en la proximidad de los espacios, del sexo que tanto nos define y acaba por confundir las rutinas, de la naturaleza que, a veces (siempre) se constata en cada uno de nuestras decisiones. Los vicios las virtudes, los deseos y las frustraciones son también esenciales puntos en 


\section{crítica de exposición}

los que se detiene su interés, materializando las carencias de una sociedad que, en su heterogeneidad, descubre la hipocresía de quienes delatan para luego asentir en silencio. Si establecemos un camino desde que se compone la imagen en el obturador hasta la definición de la luz en el papel, la fotografía solamente puede tener sentido si es admirada por otros ojos, los del espectador que tiene que desentrañar el secreto de sus proporciones, la magia de sus contrastes, la plenitud de las horas que son depositadas con esmero en la emulsión. Posiblemente, con todas las ambigüedades que resulten de las diferentes interpretaciones que se deriven en la observación de la obra de este descubridor de realidades, habrá que indagar en todo lo que nos lega como medio de confrontación para descubrir otras formas de entender y apreciar el arte de mostrar todo sin más pretensión que alertarnos de lo que somos en realidad. 